\title{
Incorporating climate change into invasive species management: insights from managers
}

\author{
Evelyn M. Beaury (D) Emily J. Fusco - Michelle R. Jackson • Brittany B. Laginhas • \\ Toni Lyn Morelli · Jenica M. Allen · Valerie J. Pasquarella • Bethany A. Bradley
}

Received: 7 March 2019/Accepted: 24 August 2019/Published online: 31 August 2019

(C) The Author(s) 2019, corrected publication 2019

\begin{abstract}
Invasive alien species are likely to interact with climate change, thus necessitating management that proactively addresses both global changes. However, invasive species managers' concerns about the effects of climate change, the degree to which they incorporate climate change into their management, and what stops them from doing so remain unknown. Therefore, we surveyed natural resource managers addressing invasive species across the U.S.
\end{abstract}

Electronic supplementary material The online version of this article (https://doi.org/10.1007/s10530-019-02087-6) contains supplementary material, which is available to authorized users.

E. M. Beaury $(\bowtie) \cdot$ E. J. Fusco · M. R. Jackson ·

B. B. Laginhas - T. L. Morelli · J. M. Allen .

B. A. Bradley

Department of Environmental Conservation, University of Massachusetts, Amherst, MA, USA

e-mail: ebeaury@umass.edu

E. M. Beaury · M. R. Jackson · B. B. Laginhas

Organismic and Evolutionary Biology Graduate Program, University of Massachusetts, Amherst, MA, USA

T. L. Morelli · V. J. Pasquarella

Northeast Climate Adaptation Science Center, U.S.

Geological Survey, Amherst, MA, USA

J. M. Allen

Department of Natural Resources and the Environment, University of New Hampshire, Durham, NH, USA about their priorities, concerns, and management strategies in a changing climate. Of the 211 managers we surveyed, most were very concerned about the influence of climate change on invasive species management, but their organizations were significantly less so. Managers reported that lack of funding and personnel limited their ability to effectively manage invasive species, while lack of information limited their consideration of climate change in decision-making. Additionally, managers prioritized research that identifies range-shifting invasive species and native communities resilient to invasions and climate change. Managers also reported that this information would be most effectively communicated through conversations, research summaries, and meetings/symposia. Despite the need for more information, $65 \%$ of managers incorporate climate change into their invasive species management through strategic planning, preventative management, changing treatment and control, and increasing education and outreach. These results show the potential for incorporating climate change into management, but also highlight a clear and pressing need for more targeted research, accessible science communication, and two-way dialogue between researchers and managers focused on invasive species and climate change.

Keywords Invasive species - Climate change · Management · Translational ecology 


\section{Introduction}

Invasive alien species and climate change are two of the most pressing anthropogenic global changes threatening ecosystems today (GBO 2014; USGCRP 2018). The consequences of biological invasions are manifold and, as climate change affects the range, abundance, and impacts of invasive species, new challenges to invasive species management are likely to arise (Dukes and Mooney 1999; Hellmann et al. 2008; Bellard et al. 2013). However, it is unclear whether natural resource managers are concerned about the influence of climate change on invasive species management, to what degree they are integrating the potential effects of climate change into management, and what barriers limit their ability to do so. Therefore, we need more information in order to facilitate proactive invasive species management that also accounts for climate change.

Climate change will likely challenge effective invasive species management in a number of ways. For example, the geographic ranges of some invasive species are expected to shift poleward and upward in elevation as the climate warms (Dukes and Mooney 1999; Bradley et al. 2010), adding new species to those currently being managed. As a result, higher latitude areas, such as the Northeastern U.S., are likely to become 'hotspots' of invasion with increased numbers of problematic species (Allen and Bradley 2016). Additionally, climate change stresses native ecosystems (Bellard et al. 2012) and increases disturbances through climate extremes (Diez et al. 2012), potentially creating new opportunities for introduced species to establish and thrive. The timing and efficacy of current treatment practices could also change if climate affects invasive species' phenology (Wolkovich and Cleland 2011), if biocontrol agents are less resilient to climate warming than their hosts (Hellmann et al. 2008), or if increasing atmospheric $\mathrm{CO}_{2}$ enhances plant growth and reduces the efficacy of chemical (Ziska and George 2004) or mechanical (Hellmann et al. 2008) control. Collectively, these changes point to the need for proactive planning and management that incorporates climate change.

Despite these challenges, climate change also affords novel opportunities for successful invasive species prevention and management. Early detection and rapid response (EDRR) at the initial stages of invasion is the most effective strategy for averting widespread invasion (Moody and Mack 1988; Mack et al. 2000; Rejmánek and Pitcairn 2002; Westbrooks 2004). Existing models of invasive species distribution shifts under climate change (e.g., Allen and Bradley 2016; Gallagher et al. 2010; Bellard et al. 2013) can characterize likely range shifts of many problematic species. These model predictions provide an opportunity for EDRR of range-shifting invasive species before they become widespread in new areas, and in areas predicted to lose invasive species overall, managers may be able to focus resources on species predicted to persist. Tools such as range shift maps and risk assessments developed through research and implemented by managers show the potential for optimizing invasive species management in a changing climate through collaboration.

However, in order to produce actionable science and improve decision-making, researchers need to work with science users from the start to understand their needs both in terms of research questions as well as research products (Arlettaz et al. 2010; Dilling and Lemos 2011; Meadow et al. 2015). This idea has been discussed previously in the invasion literature (Esler et al. 2010) and in ecology more generally (Arlettaz et al. 2010). As a result, in 2017 scientists formalized the subfield of translational ecology, defined as the "process by which ecologists, stakeholders, and decision-makers work collaboratively to develop scientific research ... that results in improved decision-making" (Enquist et al. 2017). Translational ecology approaches, which are based in the related social science paradigm of knowledge co-production (Meadow et al. 2015), depend on building trusted, committed, iterative, and two-way relationships between scientists and natural resource managers/ decision-makers from the very beginning of the research program. Such approaches are currently limited in invasive species research and management (Shackleton et al. 2019; Barney et al. 2019) but could greatly improve our ability to adapt to climate change.

A critical first step in translational ecology is to understand barriers to management success, particularly those stemming from knowledge gaps between research and practice. For invasive species management, one barrier may be a lack of communication between research scientists and resource managers, which has resulted in a "knowing-doing" gap (Pfeffer and Sutton 1999; Schwartz et al. 2019): managers may not have the time or resources to utilize a growing 
body of invasive species literature, which may be out of touch with managers' needs anyway (Bayliss et al. 2012; Matzek et al. 2014, 2015). Invasive species managers have also consistently identified lack of funding and personnel, as opposed to lack of information, as significant barriers to their success (Renz et al. 2009; Matzek et al. 2014; Kuebbing and Simberloff 2015). In contrast, managers focused on ecological adaptation to climate change often reported lack of information as a barrier because research was not applicable, clear, or accessible to managers (Archie et al. 2012, 2014; Peters et al. 2018).

Although previous studies have documented common barriers to invasive species and to climate change management separately, their combined challenges to management have yet to be addressed despite the growing evidence of the interaction between these two major forms of global change. We therefore present a first assessment of invasive species managers' information needs and barriers to effective management action in the context of climate change. By surveying invasive species managers across the United States, we assessed managers' (a) level of concern about climate change, (b) incorporation of climate change into their management, and (c) research needs about climate-adaptive invasive species management. In gathering information on these topics directly from the management community, this study provides important information to help build collaborative relationships between scientists and managers to address the challenges posed by climate change and biological invasions.

\section{Methods}

Survey and survey population

To assess managers' priorities, we developed a 22-question survey addressing three main topics, following Matzek et al. 2014 (Table 1). First, background and demographic questions asked respondents to describe their current management practices. Next, climate change questions asked respondents to identify their level of concern about climate change influencing invasive species management, the extent they incorporate climate change into their management plans, and invasive species of concern. In the final section, barriers to success and research-focused questions asked managers to identify the factors that limit their success managing invasive species, to rank suggested research topics in terms of their priority for informing their management practices (described in Online Resource 1), and to identify where they access information to inform their actions.

Under each topic, questions included short answer, multiple choice, select all that apply, and ranking on a 3- or 5-point Likert scale (Table 1). Survey questions were ordered within sections, but response options within multiple choice, select all that apply, and ranking questions were randomized to avoid bias in order. For open-ended questions, we categorized responses into groups based on their similarity.

An invitation to participate in the survey was sent by email to the following Listservs: members of the Northeast Regional Invasive Species and Climate Change Management network (173 members as of the survey initiation date in June 2018; https://people. umass.edu/riscc/), the board of the National Association of Exotic Pest Plant Councils (45 members; https://www.na-ipc.org/), members of the New York Partnerships for Regional Invasive Species Management (eight partnerships each consisting of several hundred members; https://www.dec.ny.gov/animals/ 47433.html), members of the Southeast Exotic Pest Plant Council (280 members; https://www.se-eppc. org/), and members of the Florida Exotic Pest Plant Council (343 members; https://www.fleppc.org/). Respondents were encouraged to forward the survey to colleagues and other Listservs, so the pool of respondents likely extends beyond these networks. Survey data were collected between June 20 and August 10, 2018 using Qualtrics software (Qualtrics 2018, Provo, UT). Only respondents who self-reported as natural resource managers addressing invasive species (hereafter referred to as "invasive species managers") were included in this analysis $(\mathrm{n}=295)$. We also excluded survey responses with fewer than $75 \%$ of questions answered or those where the respondent spent fewer than 4 min completing the survey ( 84 excluded for a final sample size of $n=211$ ). No identifying information was recorded, and responses to each question have been aggregated to further ensure anonymity. This study was approved by the Institutional Review Board at the University of Massachusetts Amherst (reference number 2018-4725). 
Table 1 Questions and question sample sizes included in a survey of 211 invasive species managers across the United States. The goal of the survey was to assess managers' concerns about climate change, incorporation of climate change into management, and research needs. Additional information provided in "Appendix"

Question (number of responses)
Background and demographics
Identify the percentage of your effort (sum to 100\%)
dedicated to managing each of the following invasive taxa
and habitats. (191)
What best describes your affiliation/employer? (210)

What best describes your affiliation/employer? (210)

What is the scale of the area/properties you manage? (210)

In what state(s) do you primarily manage? (209)

Identify your management priorities. (209)

Identify your highest level of education. (207)

What is your length of time in field/experience (years)? (208)

\section{Climate change}

Of your time spent managing invasive species, please indicate what percentage of your time is spent managing current invasive species versus monitoring for new potentially invasive species (sum to $100 \%$ ).

(Existing $=208$; new $=193$ )

List the invasive species you feel pose the greatest threat to your agency's management goals now (211) and in the next 5-10 years (205)

Identify your concern about the influence of climate change on invasive species management. (208)

Identify your organization's concern about the influence of climate change on invasive species management. (205)

Identify the extent to which you currently incorporate climate change considerations in your management decisions. (209)

Identify the extent to which your organization currently incorporate climate change considerations in your management decisions. (207)

If you or your organization incorporates climate change into your management decisions, please describe how. If not, please explain why not. (160 total responses of which some address 'how', some address 'why not', and some address both)

\section{Barriers to success and research}

Assess the following research topics in terms of their priority for informing your management practices: resilient native communities (201), range shifting species and hotspots (208), biocontrol efficacy (201), changes in growing season (208), changes in impacts (206), sleeper species (206), new pathways of introduction (202), changes in extreme events $(208)^{\mathrm{a}}$

Type Response options

Fill in the blank Plants, invertebrates, and vertebrates in each of terrestrial, freshwater, and marine ecosystems

Multiple choice

Municipal government, state government, federal government, non-profit, private individual, private commercial, other

Multiple choice

Single area/property, network of areas/properties within one state, regional network of areas/properties, national network of areas/properties

Select all that All 50 states and each state listed individually apply

Select all that apply

Multiple choice

Fill in the blank

Fill in the blank

Managing existing, monitoring for new

Fill in the blank

Likert

Likert

Likert

Likert

Fill in the blank

Likert Low priority, medium priority, high priority, not applicable 
Table 1 continued

\begin{tabular}{|c|c|c|}
\hline Question (number of responses) & Type & Response options \\
\hline $\begin{array}{l}\text { Drag to rank the research topics listed in the previous } \\
\text { question from highest to lowest priority for informing } \\
\text { your management practices (1-8). (199) }\end{array}$ & Drag and rank & \\
\hline $\begin{array}{l}\text { Other than the research topics listed in the previous } \\
\text { question, what topics on invasive species and climate } \\
\text { change do you think will be important for informing } \\
\text { management? (81) }\end{array}$ & Fill in the blank & \\
\hline $\begin{array}{l}\text { In general, how successful do you feel your management of } \\
\text { invasive species has been? (209) }\end{array}$ & Multiple choice & $\begin{array}{l}\text { Gaining ground, holding steady, losing ground against } \\
\text { invasive species }\end{array}$ \\
\hline $\begin{array}{l}\text { Identify the degree to which the following factors limit your } \\
\text { success in managing invasive species: agency priorities } \\
\text { (209), obtaining funding (209), personnel (208), access to } \\
\text { information (208), availability of information (208), other } \\
\text { (32) }\end{array}$ & Likert & Does not, rarely, sometimes, often, always limits success \\
\hline $\begin{array}{l}\text { Identify the degree to which the following factors limit your } \\
\text { success in incorporating climate change into your invasive } \\
\text { species management plan: agency priorities (200), } \\
\text { obtaining funding (198), personnel (197), access to } \\
\text { information (197), availability of information (197), other } \\
\text { (14) }\end{array}$ & Likert & Does not, rarely, sometimes, often, always limits success \\
\hline $\begin{array}{l}\text { Identify how useful each of the following resources is for } \\
\text { informing your invasive species management decisions: } \\
\text { primary literature (208), one-on-one conversations with } \\
\text { experts and colleagues (210), meetings/symposium (208), } \\
\text { websites (210), management documents/technical reports } \\
\text { (209), Listservs (200), online decision-making tools } \\
\text { (159), other (25) }\end{array}$ & Likert & Not useful, somewhat useful, very useful, NA \\
\hline $\begin{array}{l}\text { In addition to those listed in the previous question, please } \\
\text { list other ways of accessing information on invasive } \\
\text { species and climate change that would be useful for } \\
\text { informing your management practices. (79) }\end{array}$ & Fill in the blank & \\
\hline
\end{tabular}

${ }^{a}$ More detailed descriptions of these topics are provided in Online Resource 1 and were included in the survey ("Appendix")

Data analysis

The number of responses to individual questions varied, and unanswered questions were excluded from the analysis. Results are therefore reported relative to the sample size for each question (Table 1). When determining the primary habitats and taxa managed by survey participants, we used a cutoff of at least $50 \%$ of their time spent managing a single habitat and taxa (e.g., terrestrial plants) to indicate their primary focus.

Survey questions (Table 1) answered on a Likert scale were assigned a value of 1 to $N$ number of response options and analyzed using a Kruskal-Wallis Rank Sum Test $(Z)$. $Z$ scores were obtained by comparing fitted residuals to standardized residuals of the $Z$ distribution. To assess how employer or geographic location affected concern about climate change and the factors that limit successful management, we compared responses using a Wilcoxon Test for Pairwise Comparisons $(H)$ and the Bonferroni correction for multiple comparisons. All analyses were performed in $\mathrm{R}$ version 3.5.1 ( $\mathrm{R}$ Core Team 2018).

\section{Results}

\section{Survey population}

Survey responses from 211 invasive species managers were included in this analysis. These managers were mostly located in the Eastern United States (Fig. 1), although we received responses from managers responsible for management in all 50 states. Of these managers, the majority managed a network of properties within a single state $(57 \%)$ followed by a network of properties in multiple states (24\%) and management of a single property (16\%). One manager 


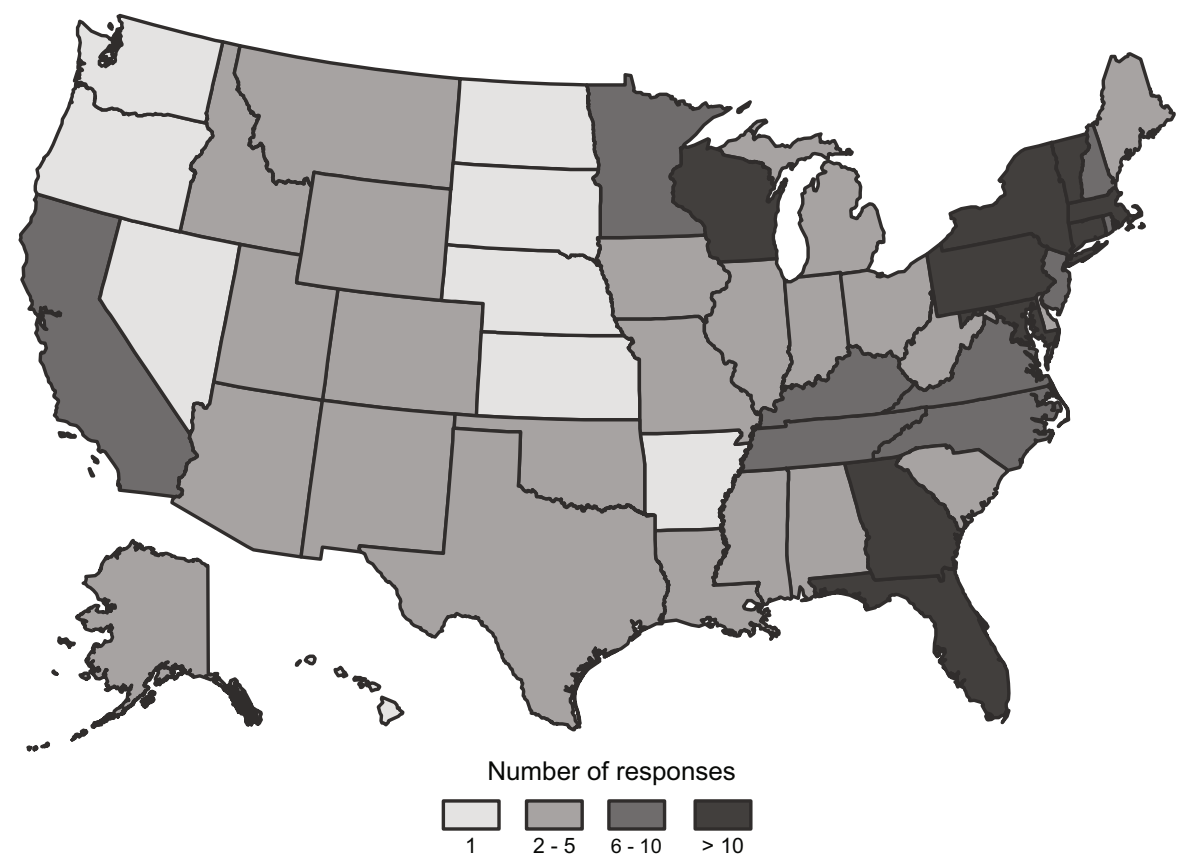

Fig. 1 State(s) where survey participants manage, including one manager who manages in all 50 states (i.e., operates at a national scale)

reported managing at a national scale. Therefore, most managers operate within a single state.

Our survey population mostly consisted of managers employed by a government agency (70\%): 35 Federal, 79 state, and 32 municipal government employees. Twenty-two percent of managers were employed by a non-profit organization $(n=47)$, and the remaining $8 \%$ were private individuals (e.g., private individual contractor or consultant; $\mathrm{n}=8$ ), employed by a private business $(n=6)$, or had other positions $(n=3)$. These managers had considerable experience, ranging from 1 to 48, with an average of $21 \pm 13.7$ years spent in the field. Additionally, 59\% of managers had earned a graduate degree.

Managers participating in the survey primarily managed to prioritize biodiversity, natural resources, and recreation (Online Resource 2), with the majority (70\%) spending half or more of their time managing terrestrial plants, followed by freshwater plants (10\%) and then all other taxa and habitats.

Climate change concern and response

Sixty-seven percent of managers in this survey reported that they were 'very concerned' about the influence of climate change on invasive species management (Fig. 2). This level of concern did not differ by geographic location, scale of properties managed, or among most employers. One exception were non-profit employees, who were significantly more likely to be 'very concerned' about climate

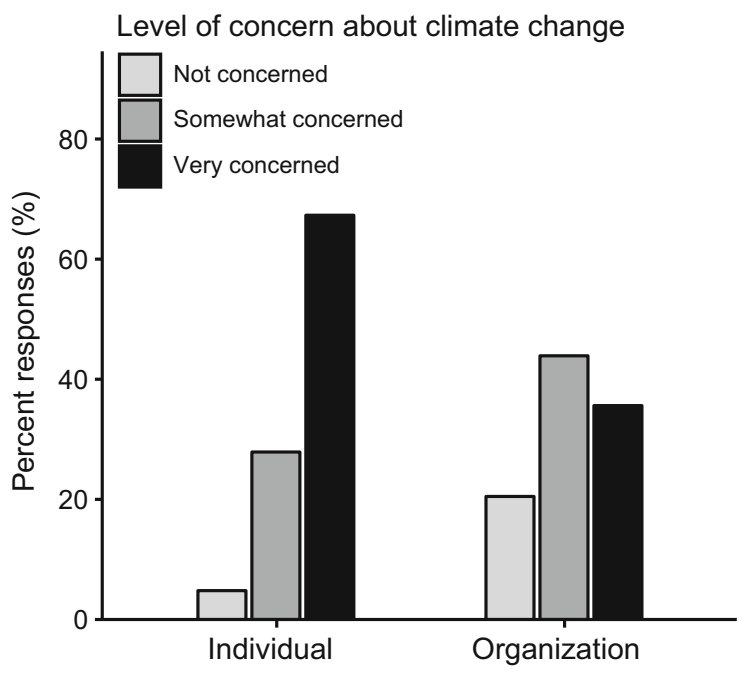

Fig. 2 Managers identified their level of concern, and perceived concern of their organization, about the influence of climate change on invasive species management 
change when compared to state government employees $(Z=-2.48, P<0.01)$. This is likely because nearly half $(44 \%)$ the state government employees were only 'somewhat concerned' about climate change whereas the vast majority $(89 \%)$ of non-profit employees were 'very concerned'. Overall, only $5 \%$ of managers reported that they were 'not concerned' about climate change.

In contrast, only $36 \%$ of managers perceived their organizations to be 'very concerned' about the influence of climate change on invasive species management, resulting in a significant difference between individual and organizational concern (Fig. 2; $H=47.25, d f=1, P<0.001)$ that was consistent for each employer, and was generally similar between states.

Most managers (65\%) reported that they incorporate climate change into their management plans $(38 \%$ 'sometimes', 23\% 'often', and 4\% 'always'), and this proportion jumped to $83 \%$ for managers who indicated that they are 'very concerned' about the influence of climate change on invasive species management (Fig. 3). Additionally, managers who were more concerned about climate change incorporate climate change in their management plans significantly more often than managers who are less concerned $(Z=-5.39, P<0.001)$. Managers reported a variety of ways in which they incorporate climate change into

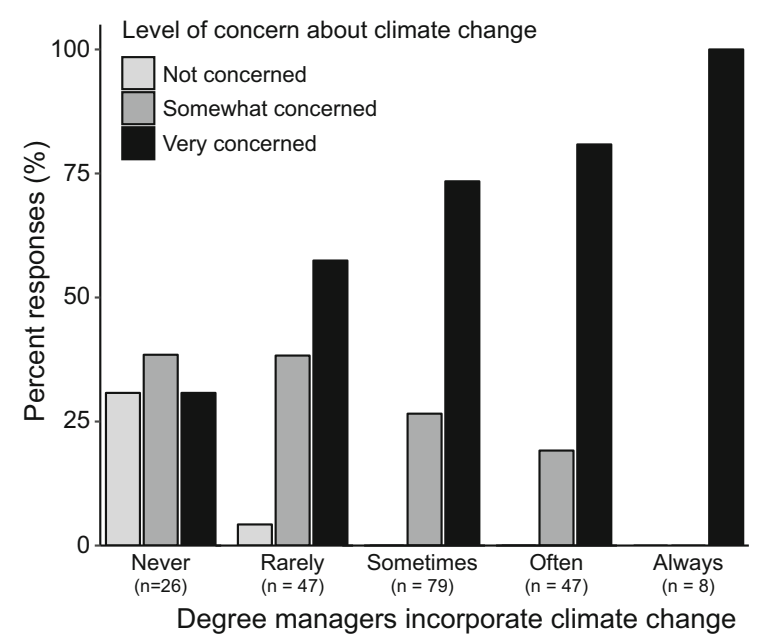

Fig. 3 The degree to which managers reported incorporating climate change into invasive species management binned by their reported concern about climate change. The number of managers who reported each degree of incorporating climate change is given, and percent concerned is out of that sample size their invasive species management, which are summarized in Table 2. Of these methods, some examples include (a) managing preventatively by monitoring for invasive species with the potential to expand their geographic ranges and by planting climate-change adapted native species from the southern margins of the properties they manage, (b) improving treatment and control by utilizing the longer growing season to treat invasive plants continuously, and (c) educating themselves and staff by attending meetings focused on climate change.

Managers also identified invasive species that they anticipate will be a threat to their management priorities within the next 5-10 years. These species included algae, fungi, invertebrates, vertebrates, and plants, although plants were most commonly reported for both current (86\% of responses) and future concerns (84\% of responses). Stiltgrass (Microstegium vimineum) and Japanese knotweed (Polygonum cuspidatum) were the most commonly listed species for both current and future threats to management priorities. The majority of managers $(67 \%)$ listed one or more species they considered future threats to their management priorities that they did not identify as current concerns, indicating that they are thinking proactively about emerging invasive species under climate change. Nonetheless, managers spend on average $90 \%$ of their time managing current invasions rather than monitoring for new invasions. Only 5\% of managers spend the majority (i.e., more than 50\%) of their time monitoring for new invasions, although the remaining $5 \%$ of managers do split their time evenly between these tasks.

\section{Barriers to success and research needs}

When asked to assess how successful their management of invasive species has been, $50 \%$ of managers reported that they are losing ground against invasive species, $32.5 \%$ are holding steady, and only $17.2 \%$ are gaining ground. Under current management conditions, lack of personnel and funding limited successful management of invasive species more than any other factor (Fig. 4; $H=400.15, d f=4, P<0.001$ ). The importance of personnel and funding limitations was consistent across the spatial scale of properties managed $(H=5.83, d f=4, \quad P=0.21)$ and type of employer $(H=8.55, d f=5, P=0.13)$, suggesting that these factors universally limit effective invasive 
Table 2 Categorized responses $(n=100)$ to the following question: "If you or your organization incorporates climate change into your management decisions, please describe how."
Frequencies exceed 100 because individual responses often listed multiple methods

Response category

Frequency

\section{Strategic planning}

Project development and planning for change

Incorporating climate change into invasive species management plans

Considering new objectives and priorities, including land acquisition

Increasing/improving partnerships across jurisdictional borders

\section{Preventative management}

Identifying and managing new invasive species

Protecting coastal resources from/adapting to sea level rise, including focusing on uplands 18

Planting native species adapted to climate change

Population/habitat management for climate adaptation

Planning for more extreme events

Managing other stressors on the landscape

Climate mitigation

Treatment and control

Changing timing of treatment and monitoring

Improving invasive species control and treatment techniques

Education and outreach

Educating self and staff about climate change

Increasing public and social engagement in invasive species removal

Talking to partners in warmer regions about their problem species and management methods

species management. However, the availability of and access to information limited success significantly more often when invasive species management also incorporated climate change (availability of information: $H=22.10, d f=1, P<0.001$; access to information: $H=15.78, d f=1, P<0.001$ ), and managers were less likely to rank factors as 'often' or 'always' limiting when asked to consider the effect of climate change on invasive species management (Fig. 4). When posed the open-ended question as to why they might not incorporate climate change into management decision-making, managers also stated that they had difficulty finding actionable information relevant to their management scale (13 responses), they were unsure how to incorporate climate change into invasive species management (10 responses), and they were too overwhelmed with present responsibilities to plan ahead for future climate change impacts (12 responses).

Managers prioritized eight suggested research topics that would reduce knowledge gaps about invasive species management in the context of climate change. When asked to rank topics relative to one another, identifying native species or communities resilient to the combination of invasive species and climate change and identifying range shifting invasive species were most often ranked as the top research priority, with changes in extreme events often falling as the lowest priority (mean ranks given in Online Resource 1). We also asked managers to rank each topic individually as low, medium, or high priority (Fig. 5). Again, identifying resilient native communities and identifying range shifting species were ranked as the highest priorities by the largest percentage of managers who responded to this question. All other research topics except identifying new pathways of introduction and changes in extreme events were considered high priority by more than a third of managers.

We also received 81 responses to an open-ended question asking managers to identify additional research topics that they think will be important for 


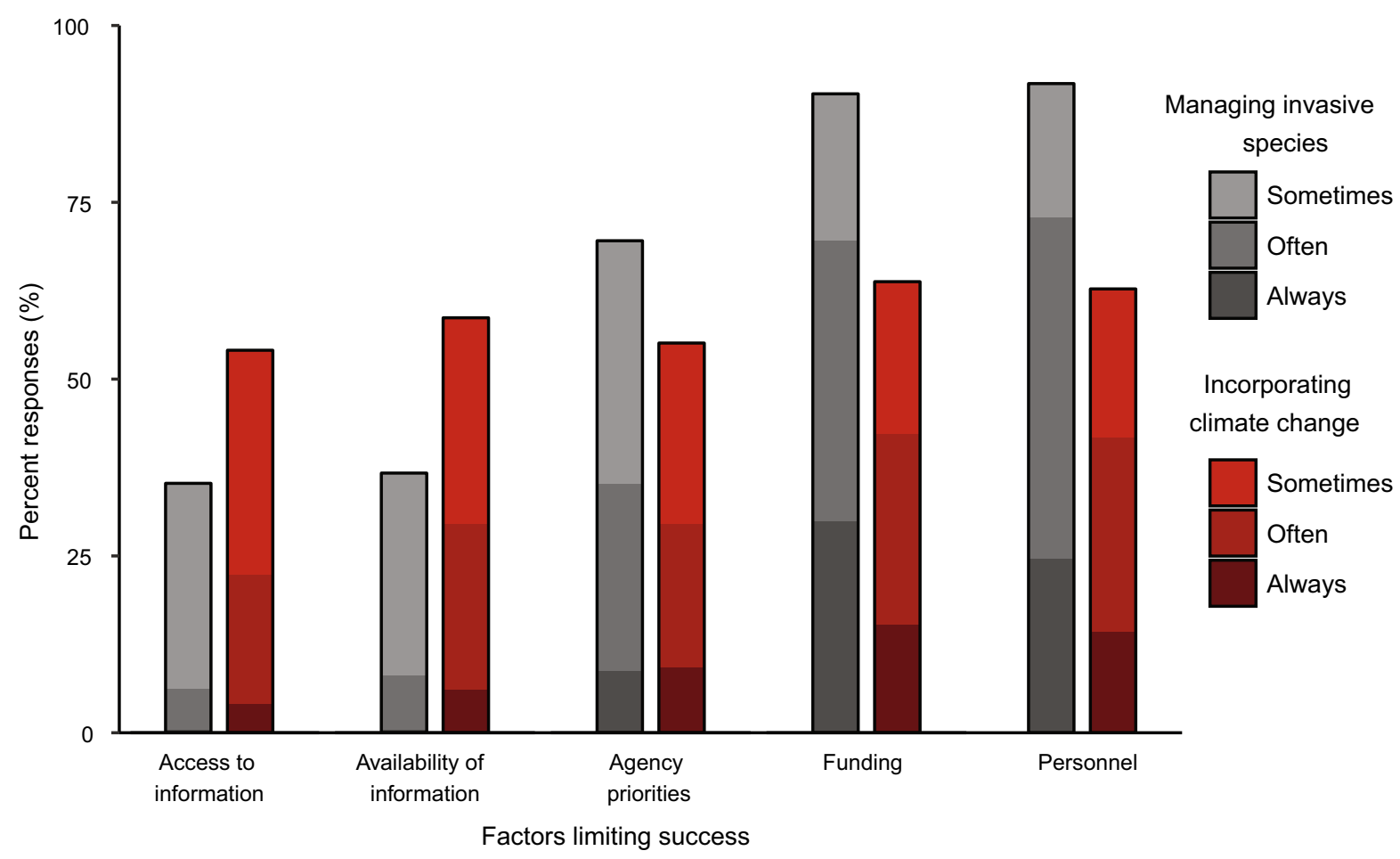

Fig. 4 Managers identified the degree to which each of five suggested factors limited their success managing invasive species in general (left bars) and their success incorporating climate change into their invasive species management plans

informing management of invasive species and climate change. Most responses (32\%) further emphasized the listed research topics (Fig. 5), and of the remaining responses, the majority concerned treatment efficacy. In particular, managers were concerned with how the efficacy of current management techniques (e.g., herbicide application, timing of mowing) will be affected by climate change, how to develop new treatment strategies to remove/eradicate invasive species, and how increasing treatments in response to climate change might impact other aspects of the environment, such as nearby native species. Managers also highlighted policy changes and increasing social and stakeholder engagement as important considerations that could facilitate effective management both currently and with future climate change. Other responses suggested the importance of understanding economic impacts of invasive species, reducing importation of non-native species through current introduction pathways (e.g., horticultural sales, exotic pet trade, accidental imports, tourism), prioritizing management objectives (e.g., what species to manage, (right bars). Percentages are only shown for managers who responded that barriers 'always', 'often', or 'sometimes' limited success. 'Never' and 'rarely' make up the remaining responses

when to stop management), and improving ways to share location-specific and species-specific management strategies.

Lastly, managers described their information use by reporting the types of communication and resources they find most useful for informing their management decisions. One-on-one conversations were by far preferred by managers, who overwhelmingly found them more useful than other forms of communication (Fig. 6; $Z>-5.7, P<0.001$ ). Primary literature was viewed as somewhat useful, but conversations, meetings, technical reports, and online information were considered more useful. Managers were the least positive about information conveyed through online decision-making tools. In an open-ended question, we asked managers to identify additional resources they find useful for informing their decision-making; managers reported region-specific resources and research summaries as other useful ways they obtain information on invasive species management. 
Fig. 5 Managers ranked each of eight suggested research topics (described in Online Resource 1) as 'low', 'medium', or 'high' in terms of their priority for informing management practices. Percentages are reported relative to the sample size for each individual research topic (Table 1)

Fig. 6 Managers ranked seven suggested resources in terms of how useful they are for informing their invasive species management decisions

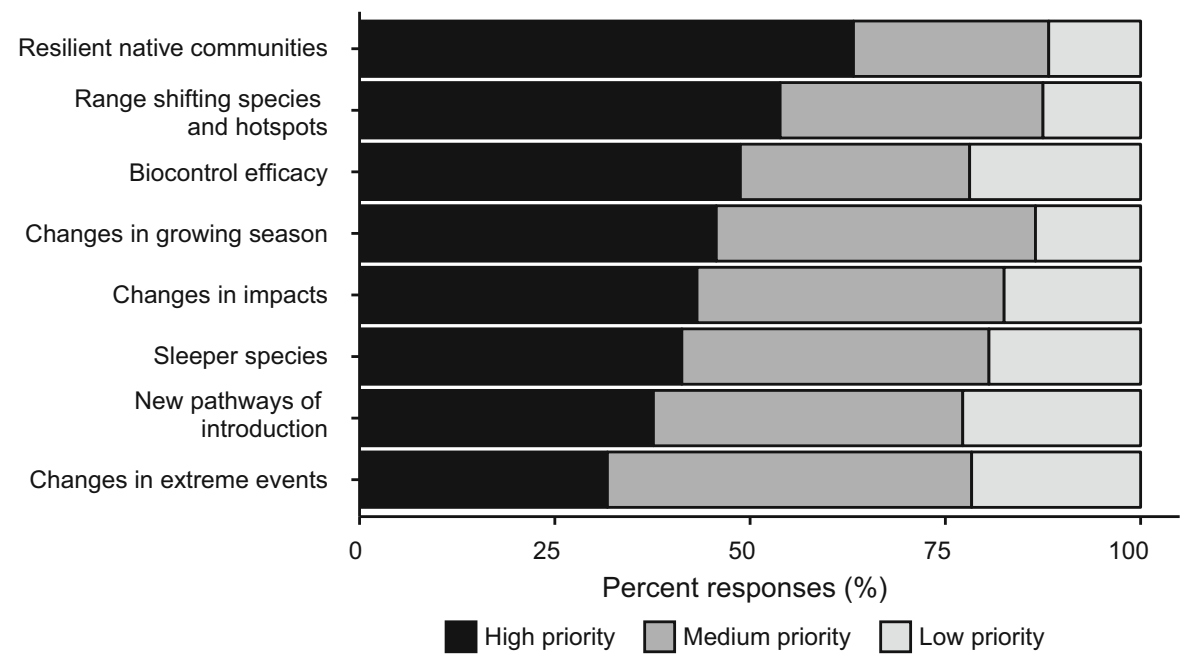

One-on-one conversations with experts and colleagues

Meetings/symposia

Management documents and technical reports

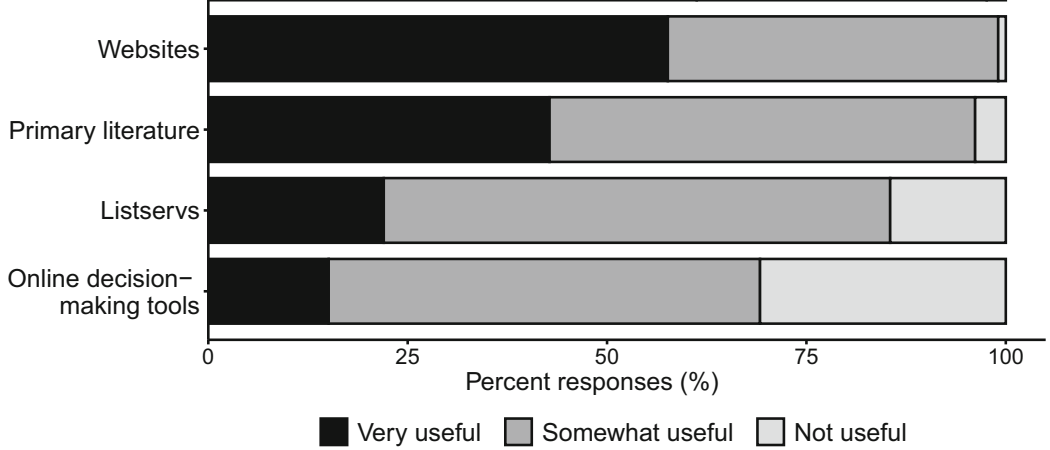

\section{Discussion}

The results of our survey indicate that the majority of invasive species managers are very concerned about the impacts of climate change on their management efforts (Fig. 2) and that the combined barriers to effective invasive species management (lack of funding and resources) and to adopting climate-smart management (lack of information) both inhibit proactive management. Nevertheless, many managers reported using a variety of tactics to incorporate climate change into their practices (Table 2) and noted their willingness to consider new objectives as well. This study therefore highlights a clear need for further integration of research and management on invasive species and climate change such that research is designed with the needs of managers in mind and management incorporates research findings (Fig. 7).

Managers consistently reported a high level of concern about how climate change might affect invasive species management regardless of the context (e.g., employer, habitat) or priorities for which they manage (Fig. 2; Online Resource 2). Invasive species managers also reported a higher level of concern than their organizations, suggesting that an increased focus on climate change adaptation would allow managers to address this issue. Archie et al. (2012) reported a similar disconnect between managers focused on 


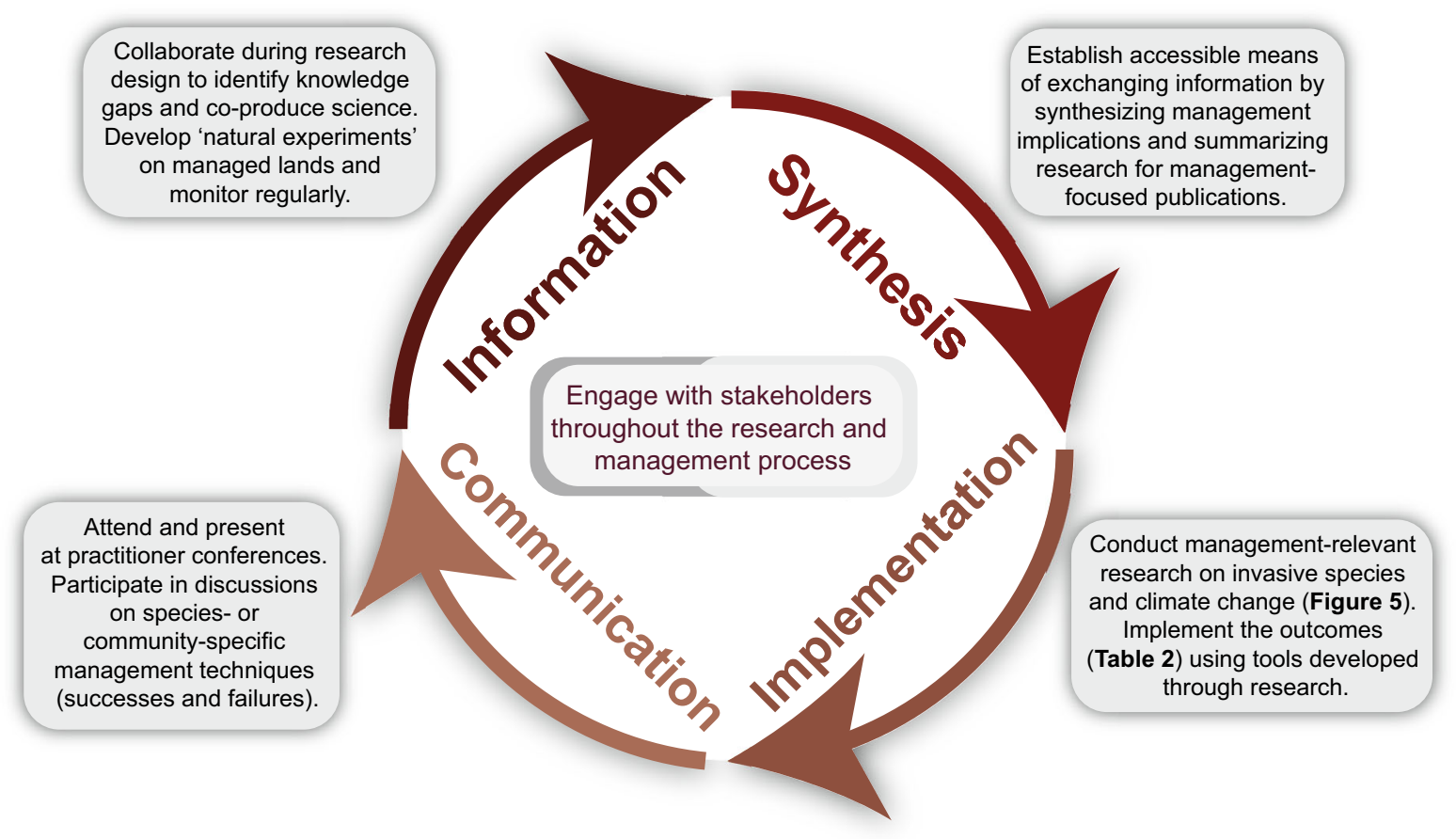

Fig. 7 A proposed framework for integrating research and management on invasive species and climate change

adaptation to climate change and their organizations, suggesting that managers' desire to plan ahead may be impeded by different priorities of their organizations.

In addition to lower organizational concern, lack of resources (funding and personnel) was frequently reported as a barrier to effective invasive species management (Fig. 4), which is consistent with several other surveys of invasive species managers (Renz et al. 2009; Matzek et al. 2014; Kuebbing and Simberloff 2015). Interestingly, when managers were asked about barriers to effective invasive species management in the context of climate change, lack of resources and lack of information were equally limiting (Fig. 4). Thus, when these two global changes are combined, barriers to effective management are also combined (e.g., Matzek et al. 2014; Archie et al. 2012). Consequently, managers spend the majority of their time focused on existing invasions and often felt that current invasive species needs overwhelmed their ability to plan ahead. Our results therefore suggest that more resources, organizational support, and research on invasive species and climate change are all important for alleviating the barriers limiting invasive species managers.
Prioritizing applied research on invasive species and climate change (Fig. 5) is one way to overcome the information challenges identified by managers (Robison et al. 2010; Mihók et al. 2015) and to ultimately increase the number of managers gaining ground against invasions. Managers are particularly interested in research on native species or ecological communities that are more resilient to the impacts of invasions and climate change (e.g., increasing natural biotic resistance; Levine 2000) and research to identify range shifting invasive species and future hotspots of invasion. Species distribution and range shift models that consider future climate change scenarios are already an active area of research (e.g., Allen and Bradley 2016; Merow et al. 2017; Petitpierre et al. 2016); such models and other tools to develop species watch lists (e.g., Environmental Impact Classification for Alien Taxa; Blackburn et al. 2014) can be used to help managers think ahead about, and monitor for future species of concern (Renz et al. 2009). Additional high priority research topics (Fig. 5) for informing invasive species management in a changing climate included understanding changes in the efficacy of biocontrol, changes in the growing season and 
species phenology, and changes in the efficacy of mechanical or chemical treatments. Herbicide use and cutting (e.g., mowing, weed whipping) are the most commonly applied invasive plant management techniques (Kettenring and Adams 2011). Research on phenology and treatment efficacy may thus be combined to consider timing herbicide application and/or cutting with climate-driven phenology changes (e.g., Stinson et al. 2018).

Improving the accessibility and applicability of scientific findings can also help to close the welldocumented knowing-doing gap between researchers and invasive species managers (Bayliss et al. 2012; Matzek et al. 2014), especially in the context of climate change. Our study suggests that research findings on priority topics (Fig. 5) would be most accessible to managers through presentations at practitioner conferences, summarized research documents aimed at a management audience, and science coproduction through research designs that focus on dialogue between stakeholders (Fig. 6), such as in translational ecology (Fig. 7; Enquist et al. 2017). Bridging the scientist-manager divide in these ways can encourage much needed, but rare (Shackleton et al. 2019; Barney et al. 2019) collaborations among invasive species researchers and managers.

In addition to formal Extension programs at landgrant institutions, several organizations provide excellent models for facilitating researcher-practitioner relationships throughout project planning, execution, and research application. For example, in 2005, a multi-institutional science team created the Sierra Nevada Adaptive Management Project (SNAMP) to provide transparency and foster mutual learning with respect to land management of forest fires in the Sierra Nevada Region (Hopkinson et al. 2017). SNAMP used a website to disseminate research information (e.g., project updates, meeting agendas, publications), facilitate regular meetings, and moderate a discussion board that allowed stakeholders to communicate directly with researchers (Kelly et al. 2012). In another example, the Northeast Regional Invasive Species and Climate Change (RISCC) Management network was established in 2016 by colleagues from the University of Massachusetts, the New York Invasive Species Research Institute, and the Northeast Climate Adaptation Science Center (CASC) to promote two-way dialogue between invasive species researchers and managers. RISCC summarizes and synthesizes primary literature (Bradley et al. 2018; Fusco et al. 2018) for an audience reached via listserv and through an annual symposium that provides managers the opportunity to give feedback to researchers, thereby facilitating the co-production of management-relevant invasive species research. The CASCs themselves are partnerships between United States Geological Survey (USGS) and university consortia focused on facilitating knowledge co-production with federal, state, and tribal natural resource managers. In another example of network building, Virginia Tech's Global Change Center brought together scientists, managers, and policymakers at a workshop focused on building collaborations between groups to improve invasive species management (Barney et al. 2019). Organizations like the CASCs and other interdisciplinary networks provide excellent examples for researchers interested in engaging with stakeholders throughout the research process. This process is swiftly gaining importance in academia as it leads to successful knowledge co-production, applicable management implications, and consideration of the social and political context of the science behind conservation scenarios (Arlettaz et al. 2010; Dilling and Lemos 2011; Meadow et al. 2015).

Despite barriers to success and increasing challenges due to climate change, many invasive species managers have successfully incorporated climate change into invasive species management (Fig. 3; Table 2). Some of the strategies described in Table 2 are not unique to climate change (e.g., managing stressors on the landscape, improving known invasive species control), indicating that incorporating climate change into invasive species management does not require a complete overhaul of current management strategies. Rather, if addressed collaboratively, climate change might be an opportunity to increase the efficiency and success of current management efforts. Several studies, including our own, have noted the importance of information exchange among natural resource managers (Fig. 6; Kuebbing and Simberloff 2015; Rafidimanantsoa et al. 2018; Barney et al. 2019) in addition to communication between researchers and managers. For example, by talking with neighbors at lower latitudes, managers may be able to limit invasive species shifting northward by increasing monitoring for target species and learning about effective (and ineffective) treatment techniques. Additionally, several of the most commonly listed methods 
of incorporating climate change into management (e.g., identifying new invasive species, educating self and staff about climate change) can already be achieved using existing research and tools. Therefore, maintaining current invasive species management objectives (e.g., regular monitoring, conserving native biodiversity), but shifting priorities to consider climate change (e.g., prioritizing management of range shifting and warm-adapted species, sharing treatment strategies) could be the most effective way to alleviate barriers to successful invasive species management under climate change (Archie et al. 2012; Enquist et al. 2017) and to improve our understanding of these global threats to biodiversity (Fig. 7).

\section{Conclusions}

The results of this survey have established a baseline on the current state of knowledge and exchange of information among research and management communities focused on invasive species in a changing climate. It is apparent that invasive species managers are likely to face new challenges due to climate change (lack of information) on top of the challenges they currently deal with (lack of resources). However, our results also show that managers will implement recommendations from the literature if research is in line with the scope and aims of management objectives and is communicated effectively. Therefore, iterative collaboration through translational ecology (Fig. 7) may be the most effective way to address barriers to successful invasive species management under climate change. We see this survey as an important contribution to this process, and we are optimistic that sharing the successes of the managers who have incorporated climate change into their management decisions will highlight the feasibility of adaptive invasive species management in a changing climate.

Acknowledgements We thank Jack Finn, Caroline Curtis, Meaghan Guckian, Audrey Barker-Plotkin, Anita Milman, and Ezra Markowitz for their help throughout this process and their insightful feedback. We are grateful to all natural resource managers who took the time to complete this survey and those engaging with the Northeast Regional Invasive Species and Climate Change (RISCC) Management Network. The project described in this publication was supported by Grant or Cooperative Agreement No. G12AC00001 from the U.S. Geological Survey and a Department of Interior Northeast Climate Science Center graduate fellowship awarded to Evelyn Beaury and Brittany Laginhas. Its contents are solely the responsibility of the authors and do not necessarily represent the views of the Northeast Climate Adaptation Science Center or the USGS. This manuscript is submitted for publication with the understanding that the U.S. Government is authorized to reproduce and distribute reprints for Governmental purposes. Any use of trade, firm, or product names is for descriptive purposes only and does not imply endorsement by the U.S. Government.

Open Access This article is licensed under a Creative Commons Attribution 4.0 International License, which permits use, sharing, adaptation, distribution and reproduction in any medium or format, as long as you give appropriate credit to the original author(s) and the source, provide a link to the Creative Commons licence, and indicate if changes were made.

The images or other third party material in this article are included in the article's Creative Commons licence, unless indicated otherwise in a credit line to the material. If material is not included in the article's Creative Commons licence and your intended use is not permitted by statutory regulation or exceeds the permitted use, you will need to obtain permission directly from the copyright holder.

\section{Appendix}

Survey administered between June 20 and August 10, 2018. This survey was distributed over email using Qualtrics. Not all results from the survey have been reported in the paper. 
1. Please complete this survey from your perspective as an individual (i.e. not the perspective of your employer), unless otherwise specified. Are you a natural resources manager?
Yes
No

2. Identify the percentage of your effort (sum to $100 \%$ ) dedicated to managing each of the following invasive taxa and habitats.
Terrestrial plants
Terrestrial invertebrates
Terrestrial vertebrates
Freshwater plants
Freshwater invertebrates
Freshwater vertebrates
Marine plants
Marine invertebrates
Marine vertebrates

3. List the invasive species you feel pose the greatest threat to your agency's management goals now.

4. List the invasive species that you expect will pose the greatest threat to your agency's management goals in the next 5-10 years.

5. Identify how useful each of the following resources is for informing your invasive species management decisions.

\begin{tabular}{|c|c|c|c|c|}
\hline & Not useful & Somewhat useful & Very useful & Not applicable \\
\hline Primary literature & & 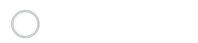 & & 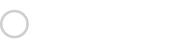 \\
\hline $\begin{array}{c}\text { One-on-one } \\
\text { conversations with } \\
\text { experts and colleagues }\end{array}$ & & 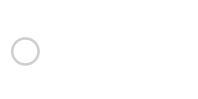 & & 0 \\
\hline Meetings /symposium & & 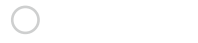 & & O \\
\hline Websites & & 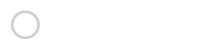 & & 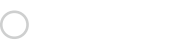 \\
\hline $\begin{array}{c}\text { Management } \\
\text { documents /technical } \\
\text { reports }\end{array}$ & & & & 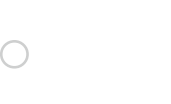 \\
\hline Listservs & & O & & O \\
\hline $\begin{array}{l}\text { Online decision- } \\
\text { making tools }\end{array}$ & & & & C \\
\hline Other: & & $\bigcirc$ & & 0 \\
\hline
\end{tabular}


6. In addition to those listed in the previous question, please list other ways of accessing information on invasive species and climate change that would be useful for informing your management practices.

7. Of your time spent managing invasive species, please indicate what percentage of your time is spent managing current invasive species vs. monitoring for new potentially invasive species (sum to $100 \%$ ).

Managing existing $(0-100 \%)$

Monitoring for new $(0-100 \%)$

8. Identify your concern about the influence of climate change on invasive species management.

\begin{tabular}{|c|c|c|c|c|}
\hline & Not concerned & $\begin{array}{l}\text { Somewhat } \\
\text { concerned }\end{array}$ & Very concerned & Not applicable \\
\hline You & 0 & & O & 0 \\
\hline Your Organization & 0 & & 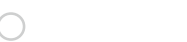 & 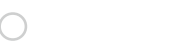 \\
\hline
\end{tabular}

9. Identify the extent to which you currently incorporate climate change considerations in your management decisions.

\begin{tabular}{c|ccccc} 
& $\begin{array}{c}\text { Never } \\
\text { incorporates } \\
\text { climate change }\end{array}$ & $\begin{array}{c}\text { Rarely } \\
\text { incorporates } \\
\text { climate change }\end{array}$ & $\begin{array}{c}\text { Sometimes } \\
\text { incorporates } \\
\text { climate change }\end{array}$ & $\begin{array}{c}\text { Often } \\
\text { incorporates } \\
\text { climate change }\end{array}$ & $\begin{array}{c}\text { Always } \\
\text { incorporates } \\
\text { climate change }\end{array}$ \\
You & 0 & & & & \\
$\begin{array}{c}\text { Your } \\
\text { Organization }\end{array}$ & & & & &
\end{tabular}

10. If you or your organization incorporates climate change into your management decisions, please describe how. If not, please explain why not.

11. Assess the following research topics in terms of their priority for informing your management practices.

\begin{tabular}{l|l}
$\begin{array}{c}\text { practices. } \\
\text { Range shifting species and hotspots: } \\
\text { Identifying range-shifting invasive } \\
\text { species and hotspots of future invasion. }\end{array}$ \\
Sleeper species: Identifying 'sleeper' \\
invasive species that are currently \\
established, but could become invasive \\
with climate change. \\
New pathways of introduction: \\
Identifying new pathways of \\
introduction that could bring novel \\
invasive species as supplies and \\
demands change with climate change. \\
Changes in frequency of extreme \\
events: Assessing how changes in the \\
frequency or magnitude of extreme \\
events (e.g. fires, hurricanes, landslides, \\
floods, etc.) could affect invasive \\
species.
\end{tabular}


Changes in impacts due to climate change: Assessing how the impacts of invasive species might change with climate change.

Biocontrol agents: Assessing whether the efficacy of biocontrol agents might change with climate change.

Resilient native communities: Identifying native species or communities that might be more or less resilient to the combination of invasive species and climate change.

12. Drag to rank the research topics listed in the previous question from highest to lowest priority for informing your management practices (1 to 8 ).

Range shifting species and hotspots

Sleeper species

New pathways of introduction

Changes in frequency of extreme events

Changes in the growing season

Changes in impacts due to climate change

Biocontrol agents

Resilient native communities

13. Other than the research topics listed in the previous question, what topics on invasive species and climate change do you think will be important for informing management?

14. In general, how successful do you feel your management of invasive species has been?

Gaining ground against invasive species

Holding steady against invasives species

Losing ground against invasive species

15. Identify the degree to which the following factors limit your success in managing invasive species.

\begin{tabular}{|c|c|c|c|c|c|}
\hline & $\begin{array}{c}\text { Does not } \\
\text { limit success }\end{array}$ & $\begin{array}{l}\text { Rarely limits } \\
\text { success }\end{array}$ & $\begin{array}{l}\text { Sometimes } \\
\text { limits success }\end{array}$ & $\begin{array}{l}\text { Often limits } \\
\text { success }\end{array}$ & $\begin{array}{c}\text { Always limits } \\
\text { success }\end{array}$ \\
\hline Agency priorities & O & $\bigcirc$ & O & O & O \\
\hline $\begin{array}{l}\text { Obtaining } \\
\text { funding }\end{array}$ & $\bigcirc$ & ก & 0 & & \\
\hline Personnel & 0 & ) & 0 & O & 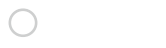 \\
\hline $\begin{array}{l}\text { Access to } \\
\text { information }\end{array}$ & O & ᄀ & 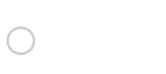 & & \\
\hline $\begin{array}{l}\text { Availability of } \\
\text { information }\end{array}$ & $\bigcirc$ & 7 & 0 & O & O \\
\hline Other: & $\bigcirc$ & O & O & O & $\mathrm{O}$ \\
\hline
\end{tabular}

16. Identify the degree to which the following factors limit your success in incorporating climate change into your invasive species management plan.

\begin{tabular}{c|ccccc} 
& $\begin{array}{c}\text { Does not limit } \\
\text { success }\end{array}$ & $\begin{array}{c}\text { Rarely limits } \\
\text { success }\end{array}$ & $\begin{array}{c}\text { Sometimes } \\
\text { limits success }\end{array}$ & $\begin{array}{c}\text { Often limits } \\
\text { success }\end{array}$ & $\begin{array}{c}\text { Always limits } \\
\text { success }\end{array}$ \\
$\begin{array}{c}\text { Agency } \\
\text { priorities }\end{array}$ & & & & & \\
$\begin{array}{c}\text { Obtaining } \\
\text { funding } \\
\text { sources }\end{array}$ & & & & & \\
& & & & &
\end{tabular}




Personnel
Access to
information
Availability of
information

Other:

17. What best describes your affiliation/employer?
Municipal government
State government
Federal government
Non-profit
Private individual
Private commercial
Other:

18. What is the scale of the area/properties you manage?
Single area/property
Network of areas/properties within one state
Regional network of areas/properties
National network of areas/properties
Other:

19. In what state(s) do you primarily manage? To select multiple, hold Ctrl (PC) or Command (Mac) key when clicking

$\square$ All 50 States
$\square$ *each state listed individually*

20. Identify your management priorities. Select all that apply.
$\square$ Fish and game
Passive recreation (e.g. hiking, kayaking)
Motorized recreation (ATVs, boating)
Biodiversity
Water resources
Forest resources
Endangered species
Rare habitats
Cultural resources 


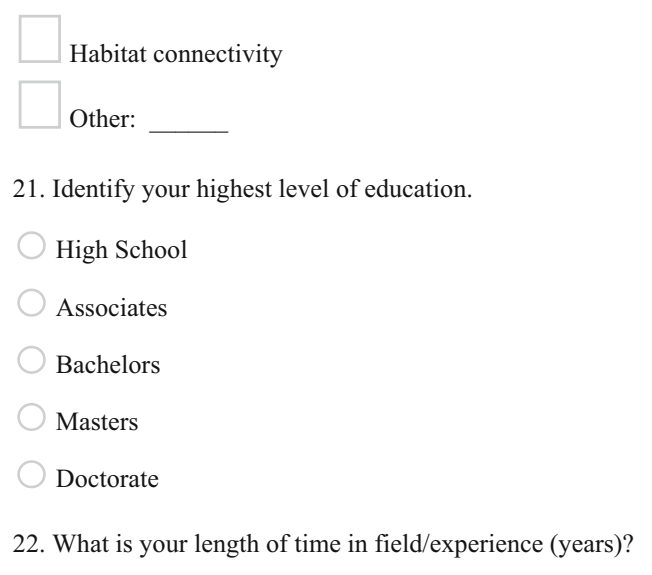

23. Please provide any additional feedback on this survey.

\section{References}

Allen JM, Bradley BA (2016) Out of the weeds? Reduced plant invasion risk with climate change in the continental United States. Biol Conserv 203:306-312. https://doi.org/10. 1016/j.biocon.2016.09.015

Archie KM, Dilling L, Milford JB, Pampel FC (2012) Climate change and western public lands: a survey of U.S. Federal land managers on the status of adaptation efforts. Ecol Soc. https://doi.org/10.5751/ES-05187-170420

Archie KM, Dilling L, Milford JB, Pampel FC (2014) Unpacking the 'information barrier': comparing perspectives on information as a barrier to climate change adaptation in the interior mountain West. J Environ Manag 133:397-410. https://doi.org/10.1016/j.jenvman.2013.12. 015

Arlettaz R, Schaub M, Fournier J, Reichlin TS, Sierro A, Watson JE, Braunisch V (2010) From publications to public actions: when conservation biologists bridge the gap between research and implementation. Bioscience 60(10):835-842

Barney JN, Schenk T, Haak DC, Salom S, Brown B, Hotchkiss ER (2019) Building partnerships and bridging science and policy to address the biological invasions crisis. Invasive Plant Sci Manag. https://doi.org/10.1017/inp.2018.33

Bayliss HR, Wilcox A, Stewart GB, Randall NP (2012) Does research information meet the needs of stakeholders? Exploring evidence selection in the global management of invasive species. Evid Policy J Res Debate Pract 8(1):37-56. https://doi.org/10.1332/174426412X620128

Bellard C, Bertelsmeier C, Leadley P, Thuiller W, Courchamp F (2012) Impacts of climate change on the future of biodiversity. Ecol Lett 15(4):365-377. https://doi.org/10.1111/j. 1461-0248.2011.01736.x
Bellard C, Thuiller W, Leroy B, Genovesi P, Bakkenes M, Courchamp F (2013) Will climate change promote future invasions? Glob Change Biol 19(12):3740-3748. https:// doi.org/10.1111/gcb.12344

Blackburn TM, Essl F, Evans T, Hulme PE, Jeschke JM, Kühn I et al (2014) A unified classification of alien species based on the magnitude of their environmental impacts. PLoS Biol 12(5):e1001850

Bradley BA, Blumenthal DM, Wilcove DS, Ziska LH (2010) Predicting plant invasions in an era of global change. Trends Ecol Evolut 25(5):310-318. https://doi.org/10. 1016/j.tree.2009.12.003

Bradley BA, Beaury EM, Fusco EJ, Laginhas BB, Morelli TL, Pasquarella VJ (2018) Regional invasive species and climate change management challenge: preparing for sleeper species. Environ Conserv Educ Mater. https://doi.org/10. 7275/R5F18WXT

Diez JM, D’Antonio CM, Dukes JS, Grosholz ED, Olden JD, Sorte CJ et al (2012) Will extreme climatic events facilitate biological invasions? Front Ecol Environ 10(5):249-257. https://doi.org/10.1890/110137

Dilling L, Lemos MC (2011) Creating usable science: opportunities and constraints for climate knowledge use and their implications for science policy. Glob Environ Change 21(2):680-689. https://doi.org/10.1016/j.gloenvcha.2010. 11.006

Dukes JS, Mooney HA (1999) Does global change increase the success of biological invaders? Trends Ecol Evolut 14(4):135-139. https://doi.org/10.1016/S01695347(98)01554-7

Enquist CA, Jackson ST, Garfin GM, Davis FW, Gerber LR, Littell JA et al (2017) Foundations of translational ecology. Front Ecol Environ 15(10):541-550. https://doi.org/10. 1002/fee. 1733 
Esler KJ, Prozesky H, Sharma GP, McGeoch M (2010) How wide is the "knowing-doing" gap in invasion biology? Biol Invasions 12(12):4065-4075

Fusco EJ, Allen JM, Beaury EM, Jackson MR, Laginhas BB, Morelli TL, Bradley BA (2018) Regional invasive species and climate change management challenge: why native? Benefits of planting native species in a changing climate. Environ Conserv Educ Mater. https://doi.org/10.7275/ 2248-hc42

Gallagher RV, Beaumont LJ, Hughes L, Leishman MR (2010) Evidence for climatic niche and biome shifts between native and novel ranges in plant species introduced to Australia. J Ecol 98(4):790-799. https://doi.org/10.1111/j. 1365-2745.2010.01677.x

Hellmann JJ, Byers JE, Bierwagen BG, Dukes JS (2008) Five potential consequences of climate change for invasive species. Conserv Biol 22(3):534-543. https://doi.org/10. 1111/j.1523-1739.2008.00951.x

Hopkinson P, Huber A, Saah DS, Battles JJ (2017) A word to the wise: advice for scientists engaged in collaborative adaptive management. Environ Manag 59(5):752-761. https:// doi.org/10.1007/s00267-017-0825-4

Hulme PE (2017) Climate change and biological invasions: evidence, expectations, and response options. Biol Rev 92(3):1297-1313. https://doi.org/10.1111/brv.12282

Kelly M, Ferranto S, Lei S, Ueda K, Huntsinger L (2012) Expanding the table: the web as a tool for participatory adaptive management in California forests. J Environ Manag 109:1-11. https://doi.org/10.1016/j.jenvman.2012. 04.035

Kettenring KM, Adams CR (2011) Lessons learned from invasive plant control experiments: a systematic review and meta-analysis. J Appl Ecol 48(4):970-979. https://doi.org/ 10.1111/j.1365-2664.2011.01979.x

Kuebbing SE, Simberloff D (2015) Missing the bandwagon: nonnative species impacts still concern managers. NeoBiota 25:73-86. https://doi.org/10.3897/neobiota.25.8921

Levine JM (2000) Species diversity and biological invasions: relating local process to community pattern. Science 288(5467):852-854. https://doi.org/10.1126/science.288. 5467.852

Mack RN, Simberloff D, Lonsdale WM, Evans H, Clout M, Bazzaz FA (2000) Biotic invasions: causes, epidemiology, global consequences, and control. Ecol Appl 10(3):689-710. https://doi.org/10.1890/10510761(2000)010\%5b0689:BICEGC\%5d2.0.CO;2

Matzek V, Covino J, Funk JL, Saunders M (2014) Closing the knowing-doing gap in invasive plant management: accessibility and interdisciplinarity of scientific research. Conserv Lett 7(3):208-215. https://doi.org/10.1111/conl. 12042

Matzek V, Pujalet M, Cresci S (2015) What managers want from invasive species research versus what they get. Conserv Lett 8(1):33-40. https://doi.org/10.1111/conl.12119

Meadow AM, Ferguson DB, Guido Z, Horangic A, Owen G, Wall T (2015) Moving toward the deliberate coproduction of climate science knowledge. Weather Clim Soc 7(2):179-191. https://doi.org/10.1175/WCAS-D-1400050.1

Merow C, Bois ST, Allen JM, Xie Y, Silander JA (2017) Climate change both facilitates and inhibits invasive plant ranges in New England. Proc Natl Acad Sci 114(16):E3276-E3284. https://doi.org/10.1073/pnas. 1609633114

Mihók B, Kovács E, Balázs B, Pataki G, Ambrus A, Bartha D et al (2015) Bridging the research-practice gap: conservation research priorities in a Central and Eastern European country. J Nat Conserv 28:133-148. https://doi.org/10. 1016/j.jnc.2015.09.010

Moody ME, Mack RN (1988) Controlling the spread of plant invasions: the importance of nascent foci. J Appl Ecol 25(3):1009-1021. https://doi.org/10.2307/2403762

Peters CB, Schwartz MW, Lubell MN (2018) Identifying climate risk perceptions, information needs, and barriers to information exchange among public land managers. Sci Total Environ 616-617:245-254. https://doi.org/10.1016/j. scitotenv.2017.11.015

Petitpierre B, McDougall K, Seipel T, Broennimann O, Guisan A, Kueffer C (2016) Will climate change increase the risk of plant invasions into mountains? Ecol Appl 26(2):530-544. https://doi.org/10.1890/14-1871

Pfeffer J, Sutton RI (1999) Knowing "What" to Do Is Not Enough: turning knowledge into action. Calif Manag Rev 42(1):83-108. https://doi.org/10.2307/41166020

R Core Team (2018) R: a language and environment for statistical computing. R Foundation for Statistical Computing, Vienna, Austria. https://www.R-project.org/

Rafidimanantsoa HP, Poudyal M, Ramamonjisoa BS, Jones JPG (2018) Mind the gap: the use of research in protected area management in Madagascar. Madag Conserv Dev 13(1):1-2. https://doi.org/10.4314/mcd.v13i1.3

Rejmánek M, Pitcairn MJ (2002) When is eradication of exotic pest plants a realistic goal. In: Veitch CR, Clout MN (eds) Turning the tide: the eradication of invasive species. IUCN, Gland, pp 249-253

Renz M, Gibson KD, Hillmer J, Howe KM, Waller DM, Cardina J (2009) Land manager and researcher perspectives on invasive plant research needs in the midwestern United States. Invasive Plant Sci Manag 2(1):83-91. https://doi. org/10.1614/IPSM-08-109.1

Robison R, Schoenig S, Johnson DW, Brusati E, DiTomaso JM (2010) California invasive plant research needs assessment. Invasive Plant Sci Manag 3(4):470-481. https://doi. org/10.1614/IPSM-D-09-00018.1

Schwartz MW, Fleishman E, Williamson MA, Willians JN, Morelli TL (2019) The use of boundary-spanning organizations to bridge the knowledge-action gap in North America. In Closing the knowledge-implementation gap in conservation science - evidence transfer across spatiotemporal scales and different stakeholders. Springer, Berlin

Secretariat of the Convention on Biological Diversity (2014) Global biodiversity outlook 4. Montréal. https://www.cbd. int/gbo/gbo4/publication/gbo4-en.pdf. Accessed 5 Mar 2019

Shackleton RT, Adriaens T, Brundu G, Dehnen-Schmutz K, Estévez RA, Fried J et al (2019) Stakeholder engagement in the study and management of invasive alien species. J Environ Manag 229:88-101. https://doi.org/10.1016/j. jenvman.2018.04.044

Sorte CJB, Ibáñez I, Blumenthal DM, Molinari NA, Miller LP, Grosholz ED et al (2013) Poised to prosper? A cross- 
system comparison of climate change effects on native and non-native species performance. Ecol Lett 16(2):261-270. https://doi.org/10.1111/ele.12017

Stinson KA, Argetsinger S, Jackson MR, Coates-Connor E, Meadows-McDonnell M (2018) Here's the dirt: the newest recommendations for garlic mustard management. Environ Conserv Educ Mater. https://doi.org/10.7275/ tmgn-7467

USGCRP (2018) In: Reidmiller DR, Avery CW, Easterling DR, Kunkel KE, Lewis KLM, Maycock TK, Stewart BC (eds) Impacts, risks, and adaptation in the United States: fourth national climate assessment, vol II. U.S. Global Change Research Program, Washington, DC. https://doi.org/10. 7930/nca4.2018. Accessed 6 May 2019
Westbrooks RG (2004) New approaches for early detection and rapid response to invasive plants in the United States. Weed Technol 18:1468-1471

Wolkovich EM, Cleland EE (2011) The phenology of plant invasions: a community ecology perspective. Front Ecol Environ 9(5):287-294. https://doi.org/10.1890/100033

Ziska LR, George K (2004) Rising carbon dioxide and invasive, noxious plants: potential threat and consequences. World Resour Rev 16(4):427-447

Publisher's Note Springer Nature remains neutral with regard to jurisdictional claims in published maps and institutional affiliations. 